\title{
Práticas de leitura em meio eletrônico
}

\section{Leilah Santiago Bufrem Tidra Viana Sorribas}

\section{RESUMO}

Discute a relação livro universitário, leitor e tecnologias, para caracterizar como os estudantes percebem as possibilidades de leitura promovidas pelo livro eletrônico. Busca entender as práticas desse leitor em relação ao novo formato do livro, analisando inicialmente um referencial teórico, para fundamentar a investigação empírica. Aplica um questionário a um conjunto de estudantes, procurando identificar características como freqüência de leitura e tempo a ela dedicado, práticas de leitura, de acordo com o suporte, os dispositivos, o gênero e o acesso. Observa que a leitura é realizada pela maioria dos estudantes na própria tela do computador, ou após a impressão do conteúdo em papel, o que corrobora afirmações obtidas na literatura. Quanto aos aparelhos de leitura, a maioria não os conhece e aqueles que conhecem não os adquiriram. Sobre o tempo destinado à leitura, ratifica o que já se tem sido constatado em pesquisas sobre essa prática, ou seja, o estudante lê pouco, em média 6,5 horas por semana entre os mestrandos e 3,67 entre os graduandos, índice relacionado a todos os tipos de leitura e suporte, em papel ou eletrônico. Conclui que embora ainda não utilizado com frequiência e até pouco apreciado, o livro eletrônico é objeto de expectativas de aperfeiçoamento evidentes, enquanto editoras inovam e criam serviços e produtos compatíveis à evolução desse campo, procurando atender a demanda pelos formatos alternativos de publicação.

\section{PALAVRAS-CHAVE}

Livro eletrônico; E-book; Leitura; Livro; Leitor 


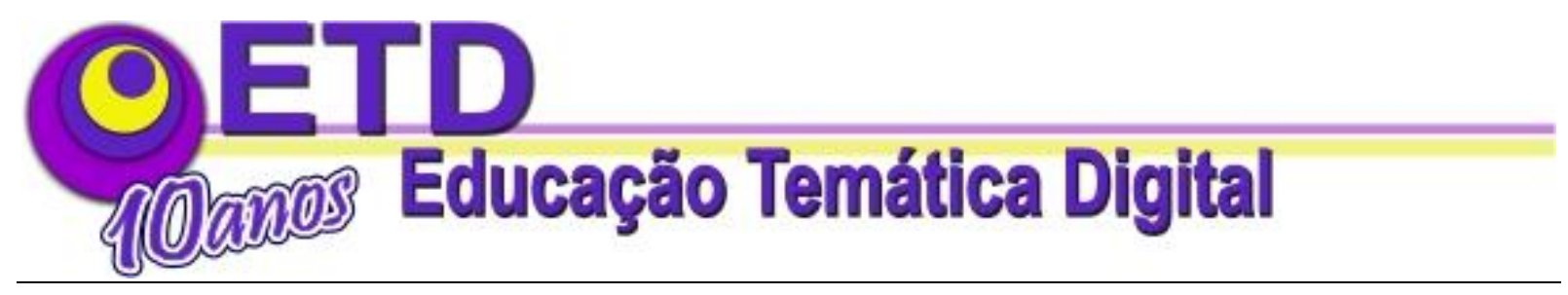

\title{
Reading practices in electronic media
}

\begin{abstract}
This work discusses the relation among university book, reader and technologies, with the aim of identify how students perceive the reading possibilities fostered by the electronic book. It seeks to understand this reader's practices towards the new book format, initially analyzing a theoretical reference, to ground the empirical survey. It submits a questionnaire to a group of students, trying to identify characteristics such as reading frequency and time spent in reading; reading practices, according to medium, device, genre and accessibility. It notes that the reading is performed by the majority of students in the computer screen, or rather after printing its contents on paper, which corroborates statements gathered from the literature. As for e-book reading devices, most students does not know them, and those who know have never purchased one. Concerning the time spent in reading, it ratifies what has been verified in other researches on this practice, that is, the student spends little time in reading, an average of 6.5 hours per week among master degree students, and 3.67 among undergraduates, in an index that points out to every kind of reading and medium, both on paper or electronic. It concludes that although it is still not frequently used and is even disregarded, the electronic book is an object of evident expectancies of improvement, while the publisher companies innovate and develop services and products that are compatible with the evolution in this field, trying to supply the demand for alternative publishing formats.
\end{abstract}

\section{KEYWORDS}

Electronic book; E-book; Reading; Book; Reader 


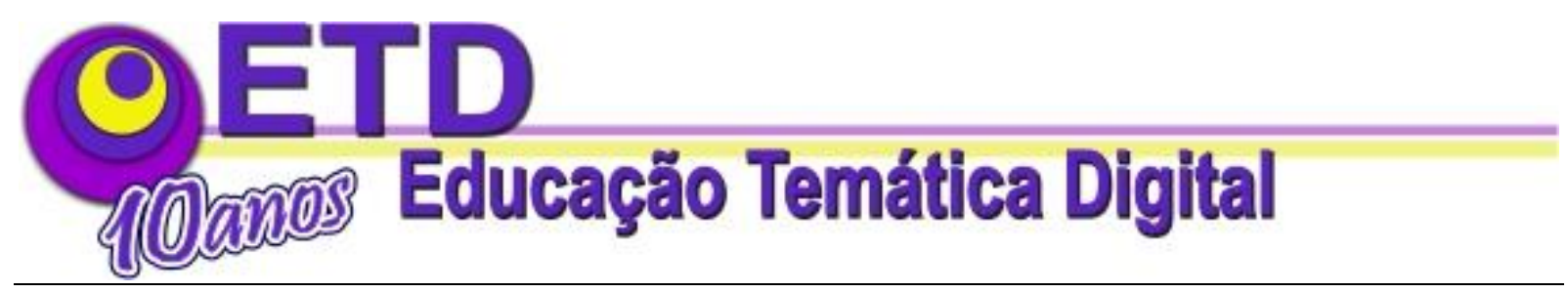

\section{INTRODUÇÃO}

A relação livro universitário, leitor e tecnologias não é inédita como objeto de estudo. Ela tem sido discutida sob o olhar acadêmico, permitindo que se antevejam expectativas quase sempre promissoras às práticas de leitura. O livro eletrônico permitiria a concretização da Biblioteca Universal, promovendo a felicidade extravagante do leitor, à qual se refere Chartier (1998) quando discute a inteligência da cultura do livro.

Essa disponibilidade dos registros do conhecimento em bibliotecas sem fronteiras desdobra-se numa vertente patrimonialista, de preservação cultural e, em outra, marcada pelo dinamismo das vozes difundidas pelos documentos, nos mais diversos formatos e suportes. São formas de acesso ao conhecimento, disponibilizadas à navegabilidade, com arquipélagos textuais sem limites (CHARTIER, 1994a) e que determinam inéditas posturas leitoras. Desdobra-se, portanto, a criatividade humana, em projetos voltados ao aperfeiçoamento do livro como instrumento de preservação e transmissão do patrimônio escrito e de acesso à leitura, sempre incentivados pela intervenção da tecnologia eletrônica.

Mas a vida de um livro não está na materialidade concreta do objeto que a sua publicação constitui. Sua vida está na “constante reinvenção que o ato de ler institui" e que se realiza com o objeto-livro, em papel ou eletrônico, "aberto para a leitura que o transforma, no próprio ato, no livro-objeto sendo reescrito ao deixar-se ler, e ser lido, enquanto escrito" (VOGT, 2008).

A construção do objeto deste estudo mobilizou o olhar investigativo à relação entre um tipo de leitor, o leitor universitário, uma leitura específica e um livro que a influencia, ao mesmo tempo em que é influenciado pelos modos de produção favorecidos pelas tecnologias emergentes. As relações dinamizadas por esse olhar desdobram-se em vertentes múltiplas, aqui recortadas epistemologicamente, haja vista a impossibilidade de explorá-las em apenas um esforço de reflexão. 


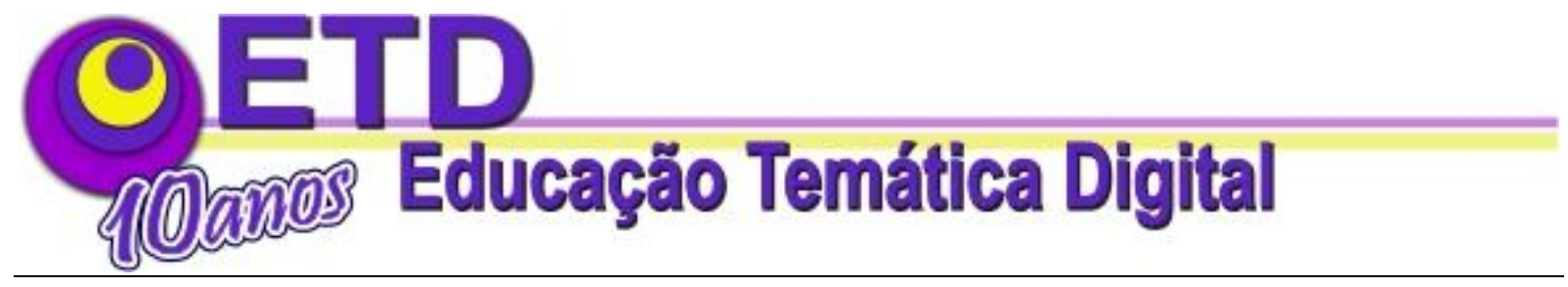

Questionam-se os modos de recepção e leitura dos estudantes universitários diante do formato do livro determinado pelos avanços da tecnologia, o denominado $e$-book ou livro eletrônico.

Ao tentar compreender essa relação, define-se o propósito de caracterizar como os sujeitos estudantes percebem as possibilidades de leitura promovidas pelo livro eletrônico e como se comportam diante delas. Entretanto, não basta conhecer o comportamento desse público leitor especial, é preciso entender como ele constrói uma postura diferenciada, diante da convivência entre livro impresso e eletrônico.

A percepção e análise dessa relação triangular, sujeito leitor, objeto livro marcado pelas tecnologias que o transformam, e o ato de leitura, como dinamizador dessa realidade, requer um movimento arbitrário em direção a cada um dos vértices dessa relação geométrica imaginária.

A análise do referencial teórico precedeu, neste estudo, a investigação empírica a um conjunto de estudantes, representado por uma amostra por acessibilidade de 22 mestrandos e sessenta graduandos do Setor de Ciências Sociais Aplicadas da Universidade Federal do Paraná e 31 de ensino médio, sujeitos que se encontravam em sala de aula nos dias da semana em que foi aplicado o questionário.

Considerando-se o atual convívio entre o livro impresso e o eletrônico, identificado como suporte semelhante ao formato de um livro ou como o próprio texto de um livro transmitido eletronicamente, aplicou-se um questionário com o objetivo de conhecer as práticas de leitura e a utilização do suporte eletrônico. Após as questões elaboradas para desenhar o perfil do leitor, procurou-se identificar características como frequiência de leitura e tempo a ela dedicado, comportamentos de leitura, de acordo com o suporte, os dispositivos, o gênero e o acesso. 


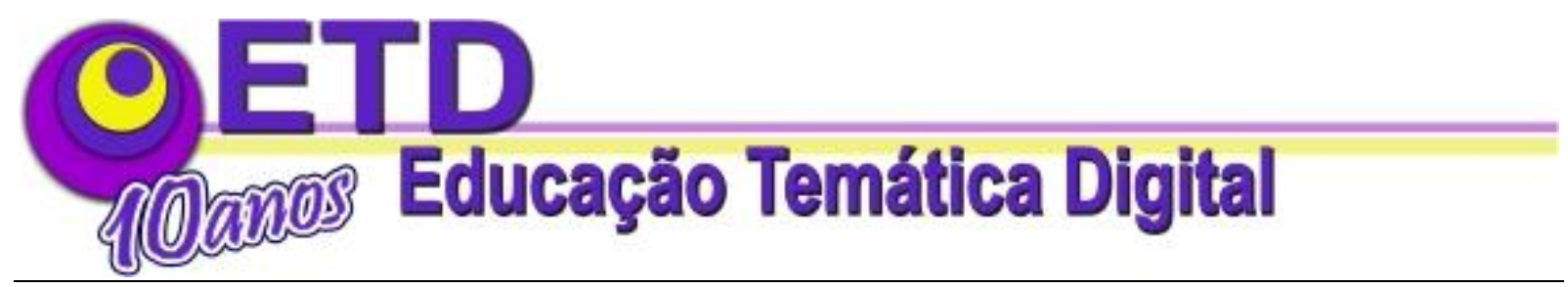

\title{
OS SUJEITOS LEITORES
}

\begin{abstract}
"Quando a última linha morreu sob o flamejamento dos olhos ávidos, houve na face do leitor um afrouxamento súbito da força vital, - um como alívio misturado de tristeza de quem se liberta de repente de um grande peso, tristeza de quem vê findar um sonho esfalfante e ao mesmo tempo suave."
\end{abstract} (OLAVO BILAC, 1923)

O sujeito leitor privilegiado neste estudo é o estudante de ensino médio e superior, aquele para quem, de um modo geral, se destinam os livros universitários. Diferentes tipos de texto e diferentes intenções mobilizam esse leitor e contribuem para sua autonomia leitora, sejam ou não textos escolares.

Se, por um lado, as relações resultantes da interação do sujeito leitor com o $e$-book ainda são pouco compreendidas, é importante considerar que este elemento mediador pode provocar grande interatividade e redução da distância entre o sujeito leitor e o texto, característica principal do meio impresso, estático em sua forma definitiva. Este ambiente virtual "é um vasto e incontrolável universo de dados que o usuário não apenas utiliza, mas pelo qual é utilizado no processo de imersão” (BELLEI, 2002, p. 142).

E esse sujeito sempre em transformação pode ser considerado um vanguardista porque realiza experimentos históricos, com textos manuscritos, impressos, disponibilizados on-line, ou com máquinas de leitura, objetos concretos que ampliam poderes de armazenamento e adquirem memória expandida. A historicidade do sujeito leitor é objeto de reflexão de Chartier, que o considera passível de transformação e adequação em virtude das mudanças sociais e tecnológicas. Entretanto não se trata de um sujeito passivo, receptáculo onde deságua a produção escrita, mas de alguém que, ao descobrir esse espaço-informação, rico em complexidade, reconhece o trabalho que essa leitura e interação requerem. 


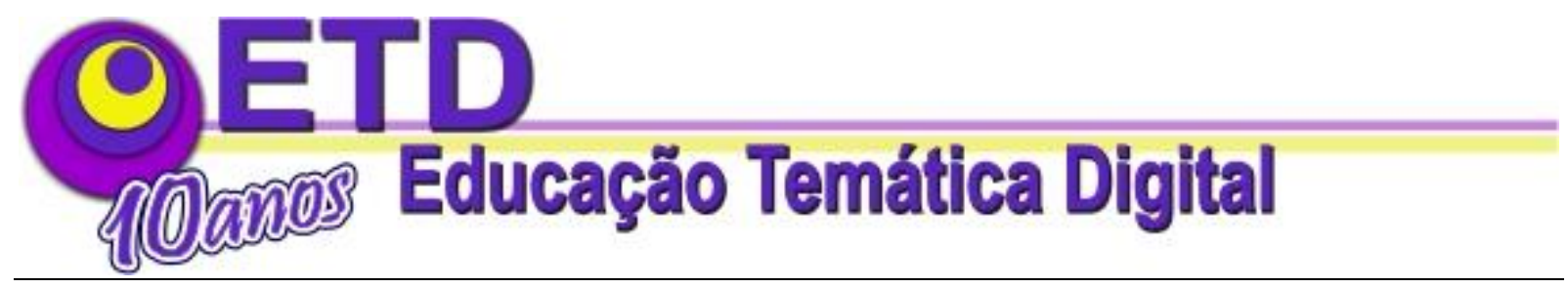

E quando se trata de leitura do hipertexto, tornam-se mais complexas as relações entre autor, texto e leitor, sobrepõem-se as janelas de leitura, alternando-se os links que rivalizam entre si, atraindo atenções. Essa permissibilidade admite ainda a manipulação do sistema, diferenciando-se da experiência tradicional de leitura pela aproximação entre sujeito e objeto.

\section{O LIVRO ELETRÔNICO}

"Dos diversos instrumentos utilizados pelo homem, o mais espetacular é, sem dúvida, o livro, uma extensão da memória e da imaginação" (BORGES, 2008, p. 9).

O livro, adequando-se às profundas transformações nos procedimentos de produção, sofreu mudanças, tanto na sua forma física, quanto na sua concepção e nos modos de uso. Aparelhos ou "máquinas de leitura" sucedem-se historicamente, demonstrando que o livro, embora tenha sofrido poucas alterações substanciais em seu formato, desde o códice, apresenta-se como um dos objetos culturais mais aperfeiçoados e apreciados da humanidade. Manuscritos ou impressos, os livros são na visão de Chartier (1994b, p. 8) "objetos cujas formas comandam, se não a imposição de um sentido exato ao texto que carregam, ao menos os usos de que podem ser investidos e as apropriações às quais são susceptíveis”.

Para melhor compreender o conceito de e-book, a forma aqui analisada, importa definir suas três acepções atuais: o livro enquanto conteúdo ou texto, representado pelo título que o determina; o processo e aplicativos editoriais que auxiliam sua leitura na tela e o recipiente ou suporte para sua leitura. 


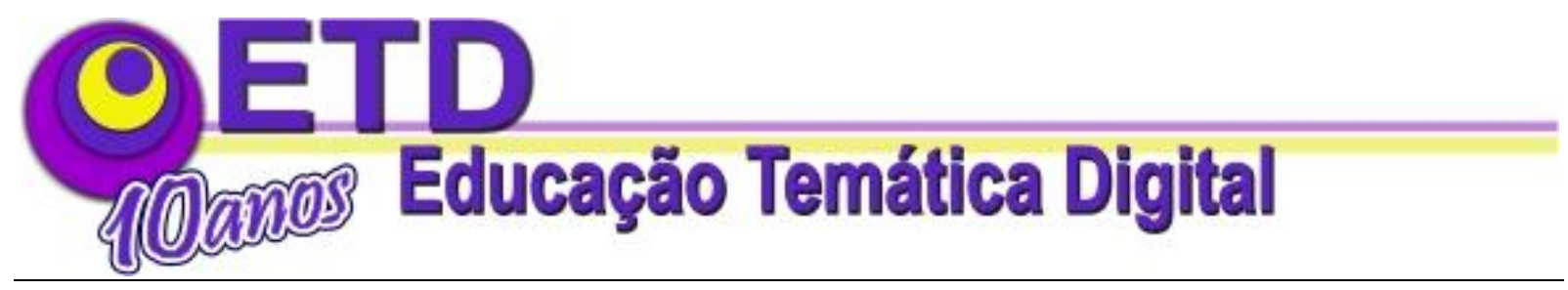

\section{Máquinas de leitura}

As feiras e exposições de livro têm apresentado as transformações promovidas pelas oportunidades da tecnologia, abrigando as inovações das editoras que já trabalham com formatos eletrônicos.

A concretização de um livro eletrônico como evolução desse objeto foi idealizada por Vannevar Bush, em 1945, que descreve o Memex, artefato capaz de armazenar todos os livros, registros e comunicações de seu dono. Em 1968, Allan Kay, cientista norte-americano da Xerox Corporation, previu o aparecimento do Dynabook, ou livro dinâmico, espécie de computador portátil, de baixo consumo de energia, com o tamanho e aspecto de um livro (SILVA; BUFREM, 2001). Em 1986, a Sony lançou mundialmente o Data Disc, um aparelho pouco maior do que um walkman, dotado de uma tela de cristal líquido e um pequeno teclado, sua forma de uso é exatamente igual à prevista para o Dynabook.

É a partir de 1998, com o Softbook, o Rocket e-Book e o Everybook que inicia uma evolução desses dispositivos de leitura. Os pioneiros eram caros, pesados e fracos em termos tecnológicos. Atualmente os modelos são mais sofisticados e de maior capacidade que os anteriores, permitindo uma leitura agradável equiparando-se à experiência de ler em um suporte impresso. Destacam-se os modelos da Sony e Amazon, respectivamente o Sony Reader e o Kindle, e-books com processadores mais rápidos, maior duração de bateria, permitindo o armazenamento de milhares de livros, além de possibilitar a almejada convergência de mídias, tais como a reprodução de arquivos de áudio, busca por uma seleção de jornais e revistas eletrônicos, e envio de e-mails utilizando conexões $W i-F i^{1}$ ou $3 \mathrm{G}^{2}$.

\footnotetext{
${ }^{1}$ Tecnologia de redes sem fios embarcadas (WLAN) baseadas no padrão IEEE 802.11.

${ }^{2}$ Padrões e tecnologias de telefonia móvel, as redes $3 \mathrm{G}$ permitem telefonia móvel de longo alcance e evoluíram para incorporar redes de acesso à Internet em alta velocidade e vídeo-telefonia.
} 


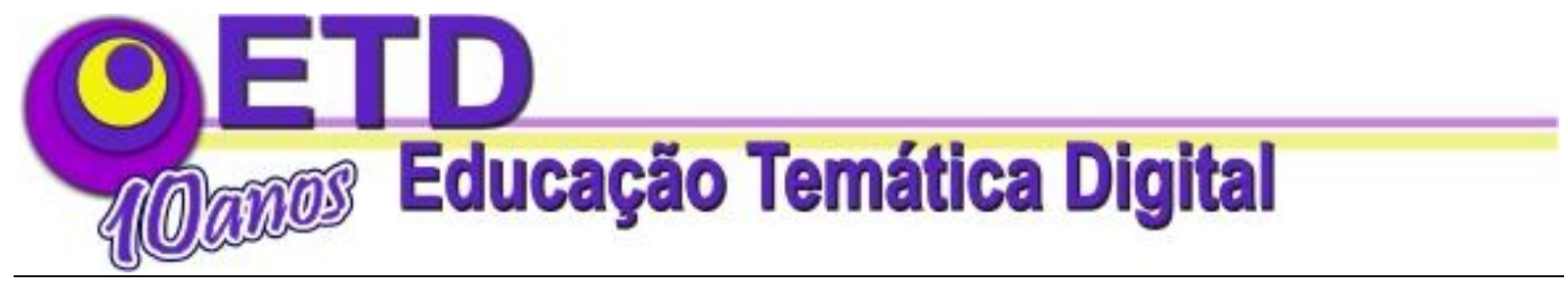

O quadro permite que se acompanhe a evolução desse suporte da escrita, o livro eletrônico, um aparelho de leitura de textos em formato digital, que oferece as funcionalidades de um livro de papel, inclusive, a mais importante delas, a portabilidade. Esta característica leva-o a ser considerado um híbrido de Palm Pilot (organizador pessoal), livro de papel e Internet. Os aparelhos atuais constituem-se em uma espécie de computador reduzido, livre de todo o supérfluo, com ausência de teclado, de periféricos, mantendo apenas as funções úteis para a leitura como virar páginas, sublinhar ou procurar palavras. Em geral é equipado com tela de cristal líquido, inserida num estojo cujo formato varia de acordo com o modelo e que funciona em conjunto com um software de leitura permitindo o aparecimento do texto.

Suas funções otimizam o conforto de uma tela e alguns modelos utilizam-se dos computadores como intermediários para o download do texto. Há também os que podem ser conectados diretamente à rede por um modem interno, permitindo a transferência do arquivo e, ao leitor, o armazenamento de uma biblioteca compactada e passível de consulta a qualquer instante. Botões permitem o avanço ou retrocesso do texto e outras funções para situar o leitor no tempo e no espaço permitem informações sobre a progressão da leitura. A possibilidade de atuar diretamente na tela táctil, com a ajuda do dedo ou de uma caneta especial, aproxima o leitor de seus hábitos em relação ao livro impresso e suas características físicas.

Essa modalidade recipiente é mediadora de um processo mais abrangente, em que atuam editores e provedores de textos eletrônicos dotados de valor cultural, de acordo com suas configurações e propósitos. 


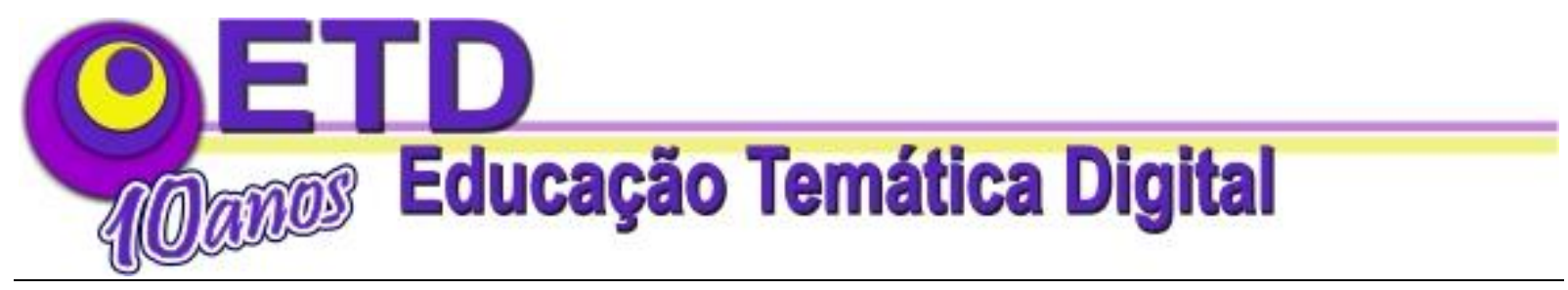

\section{Um formato de leitura: o texto eletrônico}

O livro eletrônico pode também ser definido como um texto em formato digital, obtido online via Internet, através de download, ou até mesmo em CD-Rom. Nesta outra acepção, é um texto eletrônico pois pode ser lido na tela do computador, ou em leitoras portáteis. Sob essa ótica, tem como características o uso de computadores ou de artefatos portáteis para sua leitura, a produção e a disseminação rápidas, a fácil atualização e correção do texto e seu potencial colaborativo e interativo, ensejando ao leitor a interação com o escritor, a ausência de intermediários na produção e comercialização, a maior interação da editora com o consumidor final e o alcance ilimitado, através da Internet. Eliminam-se as barreiras de envio do material, pois basta acessar o site pela rede e copiar o arquivo com o texto.

Há, entretanto, uma distinção inicial, proposta por Bellei (2002), e que se faz necessária para compreender as preocupações demonstradas por alguns autores em relação ao livro, já que o meio eletrônico pode afetar o impresso de duas maneiras: a primeira, como simples reprodução do impresso na tela; a segunda, com conseqüências mais efetivas, pois além da simples duplicação na tela, o processo modifica o livro de forma radical, transformando-o em hipertexto. Essa modalidade editorial teve como seu idealizador Michael Hart, que em 1971, quando trabalhava no Laboratório de Pesquisa e Materiais da Universidade de Illinois, decidiu iniciar a transferência de uma seleção de textos criteriosamente selecionados, para o meio eletrônico, tarefa gradativamente facilitada, graças às vantagens de disponibilização eletrônica. Livros que já estão em domínio público são transformados para formatos eletrônicos e disponibilizados no site do projeto chamado Gutenberg, que se revelou paradigmático para outras bibliotecas digitais, cujas propostas têm variado de acordo com os critérios que as modelam. Hart idealiza a ampliação da base de leitores de textos eletrônicos graças ao barateamento de tecnologias como palms e smart phones, que facilitam o armazenamento de livros eletrônicos em telefones celulares, mais do que nos outros itens citados (RODRIGO, 2008). 


\section{OETD q(0)años Educação Temática Digital}

A pesquisa da consultoria norte-americana Ithaka intitulada University publishing in the digital age (BROWN; GRIFFITHS; RASCOFF, 2007) é categórica quanto ao futuro digital das editoras universitárias. Mudanças nos hábitos e estilos de pesquisa, ensino e trabalho deverão transformar a comunidade universitária que está vendo crescer suas expectativas em relação à disponibilidade de conteúdo em formato eletrônico. Os pesquisadores e estudantes desejam não somente acessar a literatura acadêmica, mas acessar remotamente - de seus gabinetes ou de suas residências.

Bibliotecas dos campi também foram consultadas na pesquisa e foi perceptível a concordância por uma reinvenção da missão dos bibliotecários, revigorados e com melhor compreensão de seu propósito e potencial, uma combinação de:

a) auxílio à pesquisa universitária, ao ensino e à publicação de agendas, criação de coleções para apoiar a pesquisa e de ferramentas de leitura, distribuição de textos selecionados para as áreas de trabalho e de serviços especializados para os projetos de publicações e auxiliando a infra-estrutura dos cursos;

b) apoio às necessidades de leitura para estudo, criando novos espaços físicos e virtuais para trabalhos individuais ou em grupo, favorecendo leitura e pesquisa dos estudantes;

c) construção e preservação de arquivos e repositórios com as produções intelectuais da instituição;

d) digitalização e disponibilidade de coleções especiais para acesso livre e

e) promoção de acessibilidade ao conhecimento, com publicações alternativas e especialistas para negociação de contratos editoriais. 


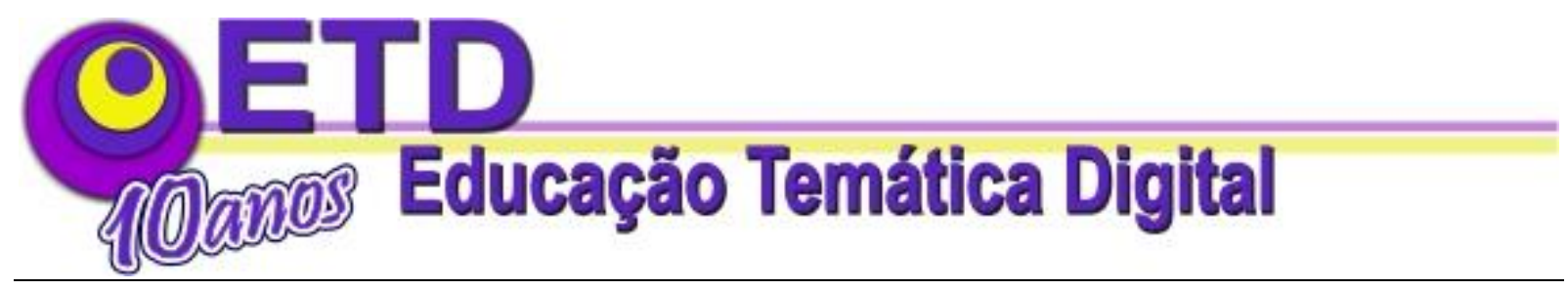

Desse modo, assiste-se a uma reinvenção dinâmica do papel da biblioteca em conjunto com as university press, como contraponto à preocupação com a desvalorização de suas funções. Como um dos centros mais vitais do campus, segundo um dos entrevistados, as bibliotecas destacam-se especialmente com iniciativas como open access (acesso aberto) e repositórios institucionais, o que as compromete com atividades de publicações selecionadas.

A pesquisa também demonstra a atuação das bibliotecas em publicações on-line, estimulando ambientes de leitura e pesquisa por meio de instrumentos ágeis. Segundo os entrevistados, esses papéis se enquadram cada vez mais no que se pode considerar como "publicação". Isso porque o papel tradicional de auxílio à comunidade local na obtenção de informações e no aprendizado de como obtê-las, com o advento dos recursos on-line passa a ser mais abrangente. Com o desenvolvimento das habilidades bibliotecárias para acessar e gerenciar esse tipo de informação, há uma necessidade crescente de assistência à produção de recursos eletrônicos, como afirma uma entrevistada: o desafio da biblioteca é criar um ambiente de pesquisa do futuro - coleções, acessibilidade e ferramentas. Portanto, há uma parceria natural entre editora e biblioteca devida a essa complementaridade entre papéis e atividades. Um entrevistado comenta que essa colaboração deve ser interativa, ágil e com novas modalidades para a criação de conhecimentos com uso de tecnologias e reinvenção de modelos.

Entretanto, a pesquisa mostra que embora os meios eletrônicos tragam benefícios indiscutíveis para a publicação de obras de referência, uma vez que o conteúdo pode ser continuamente atualizado e a leitura e pesquisa amplamente facilitadas, as editoras universitárias pouco representam para esse tipo de publicação, embora algumas já tenham destinado investimentos em novas tecnologias, passando a distribuir periódicos científicos em formato digital e cobrando mensalidades pelos acessos às áreas restritas, atendendo a necessidade de criação de ambientes de leitura e pesquisa eletronicamente integrados e procurando utilizar criativamente a multimídia nos novos produtos desenvolvidos. 


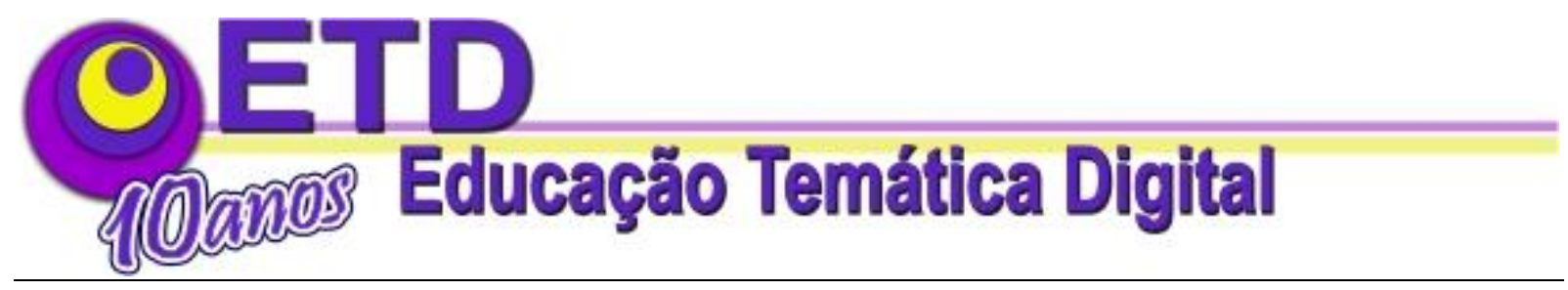

Algumas editoras iniciaram precocemente a publicação de e-books, entretanto seus resultados foram pouco expressivos. De acordo com a pesquisa da Ithaka, $73 \%$ das editoras afirmam ter publicado eletronicamente alguns livros (em projetos com NetLibrary e ebrary), mas essas tentativas não foram adequadas aos interesses de leitura dos usuários.

Além dos argumentos expostos, a ênfase dos objetivos recai na acessibilidade do leitor aos textos de interesse universitário, assim como de expandir as possibilidades de publicações do que se está produzindo na universidade.

Esse último propósito justifica-se especialmente dado o e enorme crescimento da universidade nas últimas décadas, o que traz

\begin{abstract}
um aumento igualmente considerável de sua produção editorial, tanto no que se refere à diversidade temática como no que tange ao número de títulos e livros produzidos. A universidade não é uma empresa editorial. Trata-se de uma instituição que deve ter como uma de suas funções fundamentais a atividade editorial, uma vez que o livro permanece e permanecerá como o suporte privilegiado - mesmo que não único - da transmissão da ciência, da literatura, de todas as áreas do conhecimento e da expressão humana (MARTINS FILHO, 2008).
\end{abstract}

Com os laboratórios virtuais criados nos campi, em construção conjunta entre editoras, bibliotecas e cursos, pode-se reunir e integrar uma variedade de gêneros de produção científica, desde o tradicional formato peer-reviewed como monografias, periódicos, obras de referência, a atas de comunicações de congressos, conferências, jornais, wikis (coleção de muitas páginas interligadas, em que cada uma delas pode ser visitada e editada coletivamente), repositórios temáticos, preprints, fontes primárias ou secundárias, literatura cinzenta, arquivos de dados, produtos multimídia e outros formatos híbridos.

Valter Kuchenbercker (2009), presidente da ABEU, ao refletir sobre aspectos inerentes às publicações universitárias no país, refere-se às expectativas dos editores e outros atores do mundo do livro universitário, cada vez mais procurado e lido. Defende o aperfeiçoamento das formas de colocá-lo à disposição da sociedade e, portanto, de formas de estimular a leitura. 


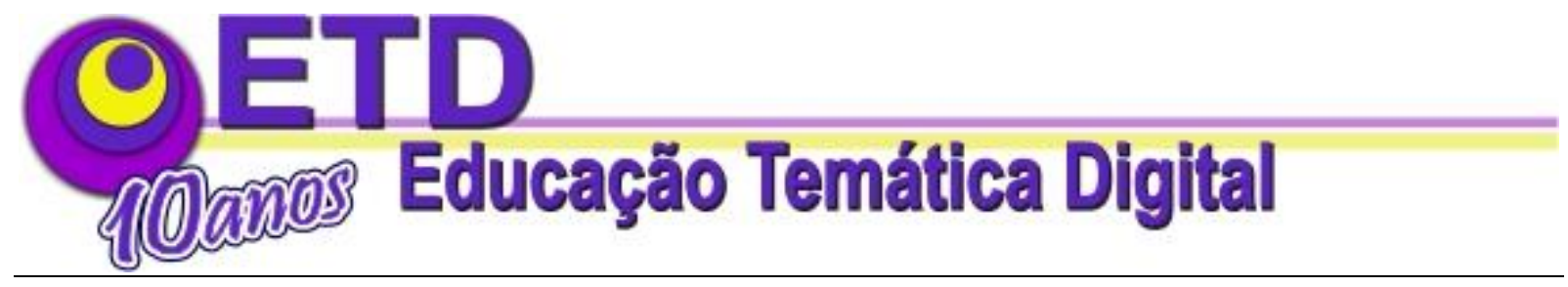

Entre essas formas, os livros eletrônicos têm sido alvo de atenções nas feiras de livros, onde a quantidade de produtos digitalizados como DVD's, softwares, filmes e livros eletrônicos vêm se destacando. Tanto em relação ao volume de produção, quanto às questões de armazenamento, o livro eletrônico tem sido uma possibilidade de solução. Inúmeros textos podem ser transferidos de um aparelho para outro sem a necessidade de descartar nenhum. Além de uma pequena biblioteca portátil, outra maior fica armazenada em casa ou no trabalho. Comparando as facilidades oferecidas pelo livro eletrônico em relação ao impresso, alguns recursos como os mecanismos de busca de palavras, hipertexto e anotações permitem ver o texto na horizontal ou vertical e acomodá-lo numa posição confortável para canhotos, permitindo, ainda, ampliação do corpo das letras conforme desejado. Os aparelhos com tela retroiluminada permitem a leitura no escuro e os leitores têm acesso a obras gratuitas visualizadas de imediato.

Alguns livros são desenvolvidos especialmente para as leitoras portáteis e outros, além de compatíveis com as leitoras, podem ser utilizados num computador. Os documentos desenvolvidos nestes softwares, geralmente são produzidos para serem comercializados, por isso são criptografados, permitindo um controle maior por parte do autor e da editora. A possibilidade de distribuição automática de direitos autorais da edição eletrônica garante o controle no momento em que o arquivo é copiado do site, quando a porcentagem e remuneração de editores e autores é calculada. A possibilidade de cópia, como o xerox, diminui, pois os textos criptografados impedem sua reprodução.

As desvantagens do livro eletrônico, de um modo geral, estão relacionadas à tecnologia a ser dominada, tanto por parte de produtores quanto de consumidores, além do fato de que o livro eletrônico consome mais energia que um livro convencional, pois precisa de eletricidade, de uma linha telefônica e bateria para o caso de utilizar as leitoras portáteis. 


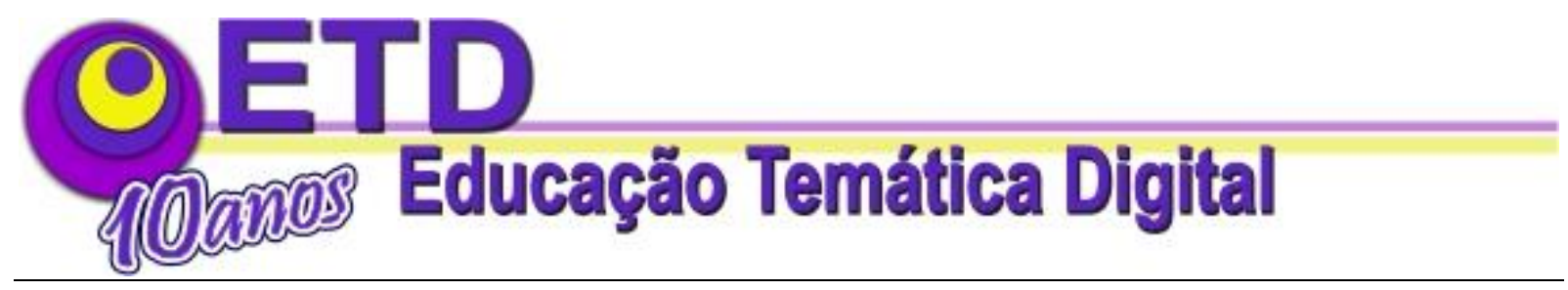

Existem sites de editoras virtuais brasileiras e editoras de outros países que comercializam textos eletrônicos em português, enquanto outros distribuem gratuitamente obras de domínio público. Um exemplo no Brasil é a Biblioteca Virtual ${ }^{3}$, idealizada pelo professor Frederic Litto da Universidade de São Paulo, que desde 1997 vem disponibilizando gratuitamente vasta quantidade de informação qualificada, atualizada e facilmente acessível, proporcionando auxílio às pesquisas escolares e servindo como subsídio para o desenvolvimento de atividades curriculares e extracurriculares. Para sua construção, colaborou a equipe da Escola do Futuro, formada por estudantes que atuam nas tarefas de programação, editoração e organização do site. A digitação dos textos é feita por voluntários, normalmente estudantes, professores ou aposentados que gostam de literatura e aproveitam para ler as obras enquanto digitam. Por serem de domínio público, as obras são distribuídas gratuitamente e disponíveis para pesquisas e download.

Lançado em novembro de 2004, o Portal Domínio Público ${ }^{4}$ constitui-se em um ambiente virtual que permite a coleta, a integração, a preservação e o compartilhamento de conhecimentos, sendo seu principal objetivo o de promover o amplo acesso às obras literárias, artísticas e científicas (na forma de textos, sons, imagens e vídeos), que constituem o patrimônio cultural brasileiro e universal, já em domínio público ou cuja divulgação seja devidamente autorizada. Ao disponibilizar informações e conhecimentos de forma livre e gratuita, o Portal busca incentivar o aprendizado, a inovação e a cooperação entre os geradores de conteúdo e seus usuários, ao mesmo tempo em que pretende induzir uma ampla discussão sobre as legislações relacionadas aos direitos autorais, em consonância com os novos paradigmas de mudança tecnológica, da produção e do uso de conhecimentos. Atualmente o site disponibiliza um total de 120.756 mídias, entre elas 106.539 arquivos de textos.

\footnotetext{
${ }^{3}$ UNIVERSIDADE DE SÃO PAULO. BibVirt: Biblioteca Virtual do Estudante de Língua Portuguesa. São Paulo, [2009?]. Disponível em: 〈http://www.bibvirt.futuro.usp.br〉. Acesso em: 15 maio 2009.

${ }^{4}$ BRASIL. Portal Domínio Público. Brasília: MEC, 2009. Disponível em: 〈http://www.dominiopublico.gov.br〉. Acesso em: 15 maio 2009.
} 


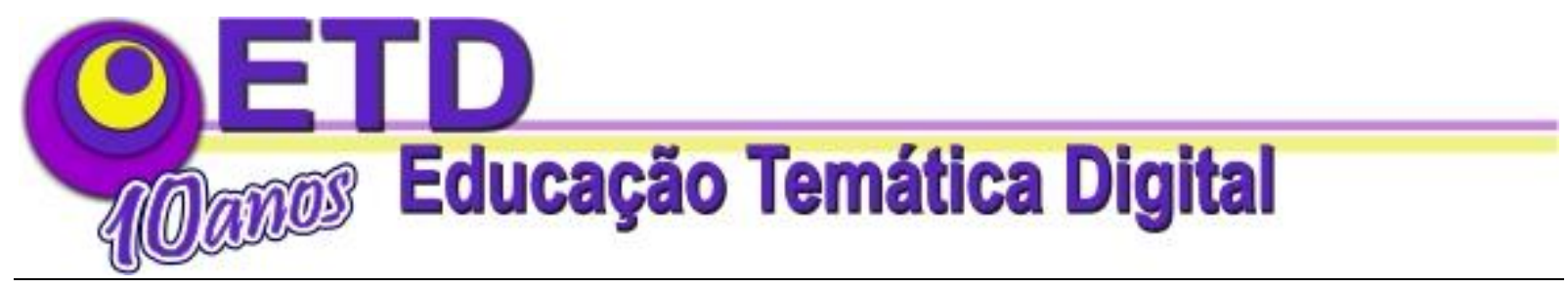

Edições sob demanda de livros digitalizados são modalidades de edição de baixo impacto ambiental, já sendo realizadas por editoras universitárias como a Editora da Universidade Sagrado Coração (EDUSC) ${ }^{5}$, em Bauru (SP), uma das primeiras a editar sob demanda no Brasil. Esse tipo de tecnologia permite que alguns livros sejam produzidos em baixíssima tiragem (entre cinqüenta e trezentas unidades), reduzindo custos de armazenagem e logística.

Plataformas totalmente digitais de produção e distribuição ainda estão em fase de estudos pelas editoras universitárias, devido aos custos relativos à estrutura e consolidação de tecnologias e treinamento de pessoal especializado.

A Fundação Editora da Unesp (FEU) ${ }^{6}$ criou o Programa de Edição de Textos de Docentes e Pós-Graduados da Unesp para editar livros nas três grandes áreas do conhecimento, Humanas, Biológicas e Exatas. Após a classificação dos originais, a Editora faz um cronograma de publicação das obras, dentro de seu calendário de edições para o ano seguinte e os livros selecionados são disponibilizados em meio digital para efetuar download e em meio físico, pelo sistema "impressão por demanda", a ser acessado pelo mesmo site. Os livros editados neste programa têm os direitos autorais regulamentados pelo sistema copyleft, em termos assinados pelo autor e pela FEU.

\footnotetext{
${ }^{5}$ EDITORA DA UNIVERSIDADE DO SAGRADO CORAÇÃO. Bauru, SP, 2008. Disponível em: 〈http://www.edusc.com.br>. Acesso em: 15 maio 2009.

${ }^{6}$ FUNDAÇÃO EDITORA DA UNIVERSIDADE ESTADUAL PAULISTA. São Paulo, 2009. Disponível em: 〈http://www.editoraunesp.com.br>. Acesso em: 15 maio 2009.
} 


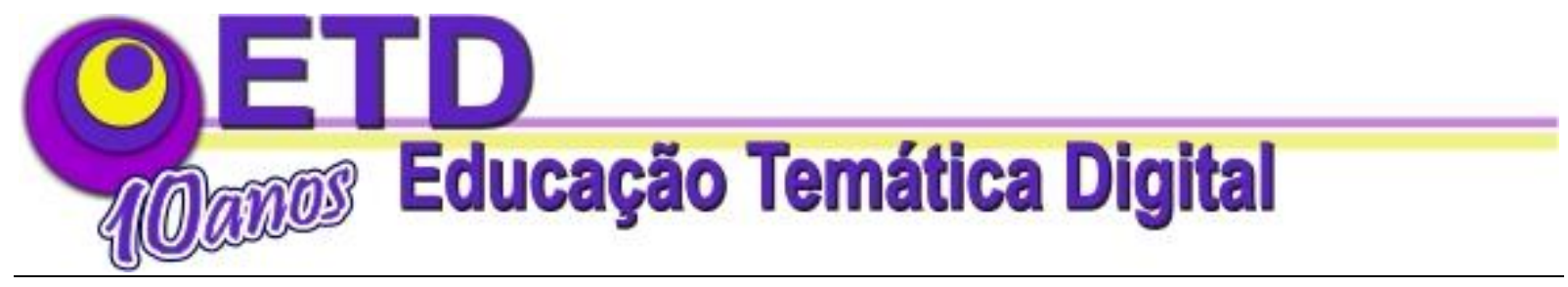

A motivação das editoras tem sido a redução dos custos de impressão, de modo a garantir a sobrevivência das editoras no modelo de mercado competitivo. Entretanto, as oportunidades de acesso a essa literatura repercutem nos modos de recepção dos leitores, motivando-os a processos de busca mais direcionados e permitindo que recebam informações atualizadas sem saírem de suas mesas de trabalho. Para Enio Rodrigo (2008) essa plataforma é uma grande oportunidade para as editoras universitárias ampliarem seu público, otimizando a distribuição dos livros e o problema da dependência de lojas físicas, e ampliando a divulgação de obras.

Os dois softwares Acrobat Reader e o Microsoft Reader, a seguir descritos, são os mais citados na literatura, razão pela qual foram selecionados como exemplo para ilustração.

Atualmente o Acrobat Reader ou formato PDF (portable document format) é considerado básico e obrigatório para a transferência de arquivos. Este programa permite a leitura de todos os documentos no formato PDF, o mais utilizado para a transmissão de documentos formatados. Apresenta vantagens destacáveis como o volume dos fichários e sua visualização com o programa gratuito Acrobat Reader; o formato numérico que garante uma apresentação fiel dos documentos originais; a diagramação profissional perfeita, tanto na tela como no papel; as funções de navegação e de zoom que permitem um aproveitamento melhor do texto e das imagens dos PDF, entre outras.

Geralmente o grande problema encontrado pelas pessoas que querem ler livros pela Internet, é como baixar o livro e que ferramenta usar. Documentos do Microsoft Office e PDF são formatos muito vagarosos para abrir e em até certo ponto são complicados de manusear.

O programa Microsoft Reader foi concebido para oferecer leitura análoga à do papel. Dispõe da inovação para a resolução dos caracteres nas telas em cores, e incorpora também as vantagens da tipografia e do desenho tradicionais, o que permite uma apresentação clara, com grandes margens, textos alinhados, com espaços equilibrados entre as palavras, 


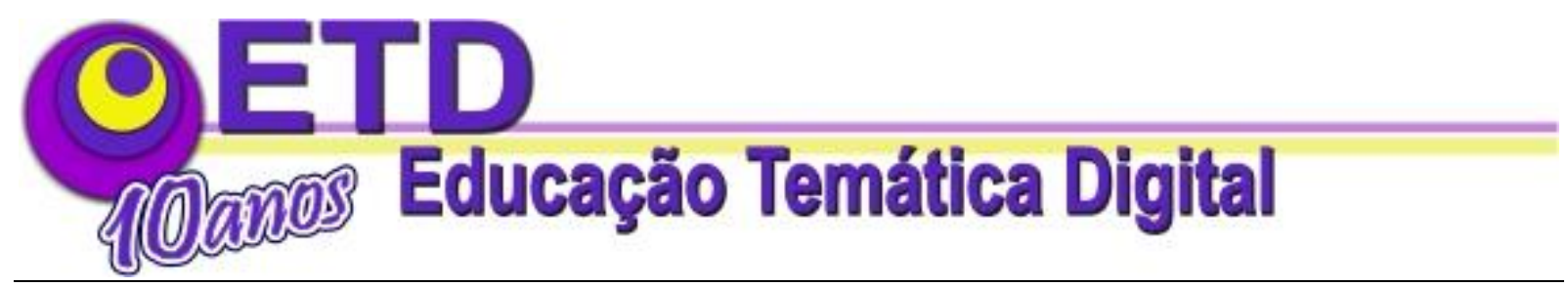

assim como utensílios para anotar, sublinhar, selecionar passagens, marcar páginas, apresentando também opções para ajustar o texto. Além disso, conta com um dicionário integrado e uma biblioteca que pode conter e classificar um grande número de livros e outros documentos. Por ter interface muito parecida com um livro, permite que se passem as páginas mais ou menos rapidamente; da mesma forma que se folheia um livro manualmente, para encontrar uma determinada ilustração ou um quadro. No caso de livros em inglês, alemão ou francês, há uma ferramenta que habilita o programa a ler o livro em voz alta.

\section{A LEITURA}

"Creio que uma forma de felicidade é a leitura". (BORGES, 2008)

A concepção do ato de ler como apropriação, invenção ou produção de significados, implica a valorização da liberdade do leitor ao deslocar ou até mesmo subverter o texto alvo de sua atenção. Se este ato de leitura e subversão é estimulado pela agilidade e dinamismo causados pelos meios eletrônicos, pelas possibilidades do hipertexto ou pelas manobras permitidas pela manipulação do texto eletrônico, é possível falar numa formação cultural inédita e revolucionária, em que a leitura deixa de ser um ato solitário, que afasta e isola o leitor, para permitir uma situação inédita que estabelece outros tipos de interações, além daquela dialógica, verificada entre leitor e autor, ou entre leitor e contexto do discurso, ou ainda, entre leitor e outros leitores. Desdobra-se ainda para possibilidades relacionadas às repercussões da obra relativas aos procedimentos interpretativos e críticos do leitor diante das virtualidades dos meios eletrônicos.

Com vantagens específicas para o leitor, dadas as possibilidades ao seu alcance diante da transmissão eletrônica, uma espécie de revolução da leitura contribui para uma geração de leitores que aprendeu ou vem aprendendo a ler na tela, a uma velocidade maior que a dos mais versados mestres educados no papel (PERSONA, 2000, p. 2). Além da disponibilização pura e simples do texto, as formas hipertextuais, ao permitirem uma leitura não-linear, aproximam o ato de ler do ato de criar e recriar no próprio texto. 


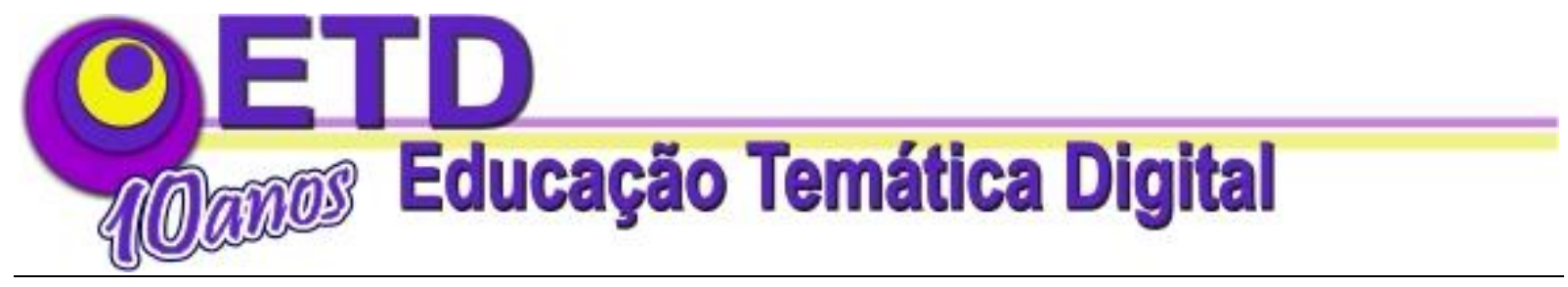

No momento em que se celebram as novidades da escrita e da leitura no novo meio, argumenta Loth (2003), deixa-se de buscar a sua historicidade no contexto de uma série de obras e autores que se preocuparam em quebrar formalmente a estrutura linear e a fixidez do texto impresso.

Essa abolição da linearidade foi ambição de autores como, Marcel Proust, James Joyce, Júlio Cortazar, Jorge Luiz Borges e Lawrence Sterne, que estruturaram seus textos de maneira alternativa, permitindo ao leitor superar padrões convencionais de distribuição textual. Esses autores buscaram uma espécie de subversão da ordem, ao tentarem romper uma narrativa considerada linear, o que se aproxima de uma forma de pensamento hipertextual na literatura, como se estivessem esperando pelo computador para libertá-los do impresso. Muitas de suas obras poderiam ser transferidas para o espaço da escrita hipertextual e nele plenamente reconstruídas (BOLTER, 1991, p. 132). Vale destacar que algumas dessas obras já denunciam a influência do uso do computador na produção literária e as relações da informática com a escrita. Características freqüentemente atribuídas ao hipertexto encontramse, desse modo, dispersas ao longo da tradição literária não se limitando a períodos datados, mas muitas vezes reunidas em uma mesma obra, como é o caso de O Dicionário Kazar, analisado por Loth (2003). É válido afirmar ainda, que o hipertexto é um artifício cultural, inserido em um conjunto de práticas artísticas e intelectuais. Está ligado à própria forma de narrar e pensar o mundo, permitindo que seus links, referências simples ou cruzadas ampliem o conhecimento sobre a obra e seu conteúdo, os aspectos ainda desconhecidos relacionados com o tema ou o significado de uma palavra apenas clicando sobre ela. A leitura torna-se uma espécie de jogo criativo e intertextual. 


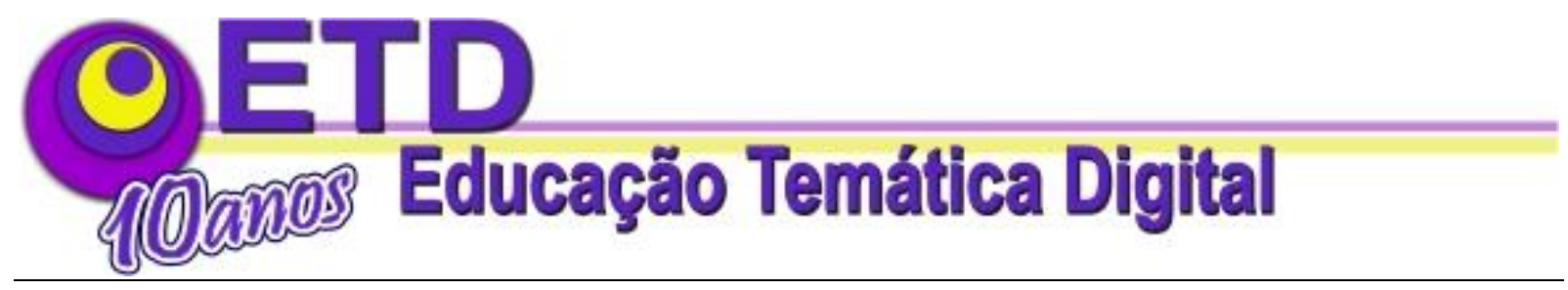

Ao afirmar que "há uma coisa engraçada acerca da fusão de tecnologia e cultura" (2001, p. 8), Johnson alerta que ela fez parte da experiência humana desde o primeiro pintor das cavernas, mas temos tido muita dificuldade em enxergá-la.

\begin{abstract}
Quando James Joyce publicou Ulisses em 1922 e revolucionou todas as nossas expectativas quanto ao que os livros devem ser, estava sendo assim tão diferente do próprio Gutenberg? Não se podia ver isso na época, mas Joyce era um técnico altamente qualificado que andou fazendo experiências com uma máquina-livro, levando-a a fazer coisas que nunca fizera. Seus contemporâneos o viram como um artista (ou, muitos, como um pornógrafo), mas do nosso ponto de observação ele poderia perfeitamente ser visto como um programador que escreveu códigos para a plataforma da máquina impressora. Joyce escreveu software para um hardware originalmente materializado por Gutenberg.
\end{abstract}

O processo de surgimento e difusão do texto eletrônico contém, da mesma forma, uma ruptura com os modos de leitura que o antecederam, razão pela qual a análise das formas de apresentação e uso do livro permite que se transcendam as interpretações limitadas a uma dimensão tecnológica, em prol de uma ampliação da análise para situações que caracterizam o cenário da vida cotidiana. A revolução do texto pode envolver a criação, o acesso e a intervenção sobre informações estratégicas, sejam de natureza econômica, política, científica ou ética, de qualquer forma, informações sobre a informação.

Concretizado eletronicamente, o livro pode influenciar a maneira pela qual os sujeitos fazem suas leituras, profissionais de informação cumprem suas práticas e editores realizam sua missão. Sua interação com o sujeito leitor repercute também nas tecnologias para sua perfeita utilização, de modo especial nos desenhos dos programas que oferecem as instruções de funcionamento que são executadas pela máquina. Modificações no modo de estruturar o escrito, de organizar o material de leitura em textos dispostos na Internet resultarão em outras formas de recepção e acesso ao livro. $\mathrm{O}$ ato de ler vê ampliadas suas possibilidades diante das novas estruturas textuais, dos elementos que se conjugam e integram na concretização do escrito. E se influenciam os modos de escrita, esses elementos por certo influenciam os modos de leitura dos textos, dinâmicos, ágeis e desafiantes, marcados muitas vezes pela agilidade, brevidade e com uso de regras próprias, como afirma Coscarelli (1996): 


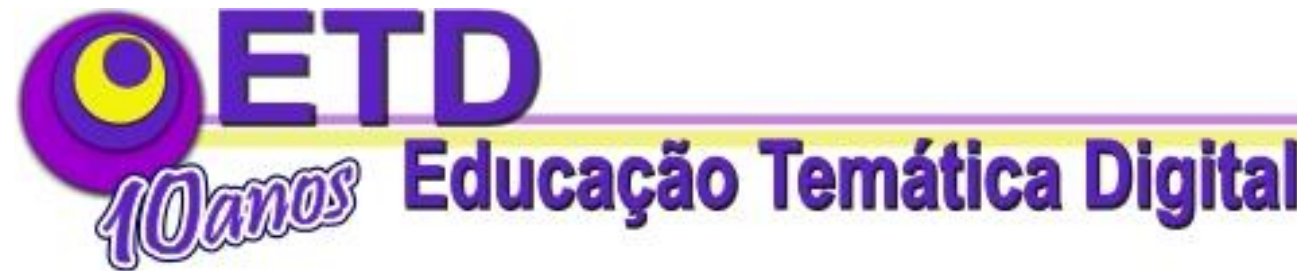

Além desses novos gêneros textuais, é interessante verificar a existência do próprio hipertexto que instaura uma nova forma de leitura. Afinal, sem qualquer delimitação, no âmbito virtual, pode-se começar a ler um texto e linkar para um outro texto e ir navegando para outros textos, que se, de alguma maneira, remetem ao primeiro, desvinculam-se dele.

Prevê-se para um futuro próximo jornais e revistas impressos em papel digital ou e-paper leve, fino e flexível, utilizando "milhões de cápsulas microscópicas preenchidas por pigmentos claros e escuros que se tornam visíveis quando ativados por uma corrente elétrica". Bem mais resistente do que os atuais monitores de cristal líquido (LCD) usados em notebooks, esse display digital de apenas duas páginas cujas pontas podem ser dobradas, tem páginas que podem ser constantemente mudadas (GONÇALVES-CHAVES, 2005).

Citado por Rodrigo (2008), Jezio Gutierre, editor executivo da Editora da Unesp, observa que o hábito de leitura depende do objeto lido e do leitor e prevê que as mudanças nos hábitos de leitura não devem demorar, mas serão diferentes em cada país, portanto, as editoras universitárias têm que estar preparadas para novos desafios.

Aceitar os desafios depende também de situações conjunturais nem sempre adequadas às expectativas editoriais, razão pela qual o design de produção do livro que, segundo Martins Filho (2008, p. 53), tem apresentado desenvolvimento irregular nas últimas cinco décadas, é reflexo do desenvolvimento artístico e técnico de uma determinada época: "Esse desenvolvimento não chegou ao fim. A publicação em desktop, a montagem da página na tela do computador, em razão do advento da composição e da ilustração digitalizadas, abrem novo campo para várias possibilidades (e riscos!) de criação.”

Assumir os riscos de criação, unir elementos estéticos aos técnicos, requer especialmente uma crítica à prática, com conhecimento de causa, respeitando-se as heranças históricas de antigos tipógrafos sem, entretanto, cair no anacronismo. Esse compromisso criativo dirige-se de modo especial ao sujeito leitor como argumenta Morrison (apud MARTINS FILHO, 2008, p. 53) quando propõe “ajudar ao máximo o leitor a compreender o texto.” 


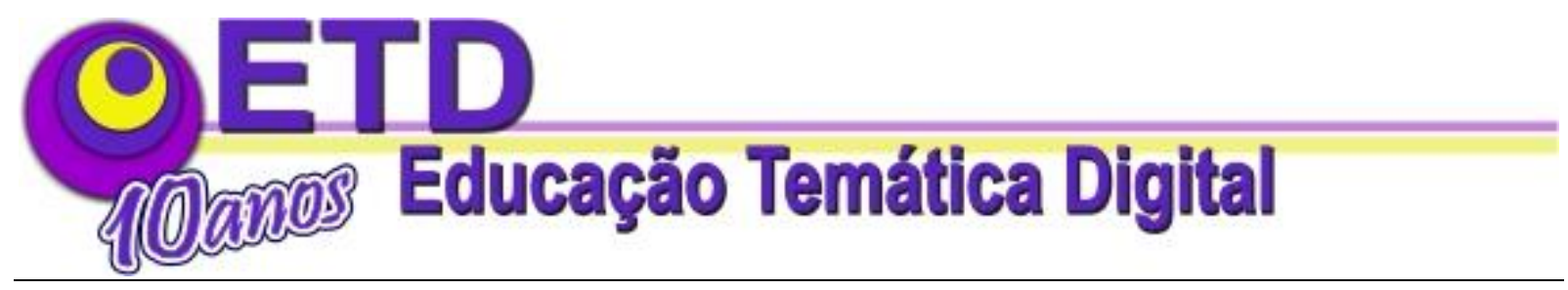

No caso da editora universitária, é um leitor especial que sente e percebe o texto, mas é um leitor. A ampliação de sua capacidade de leitura e interpretação pode ser parcialmente decorrente da arte de dispor corretamente registros, distribuir os caracteres, as letras os espaços e controlá-los de acordo com a finalidade específica de auxiliar, sem interferir, entretanto, no fluxo necessário que deverá haver entre autor e leitor. A defesa dessa idéia é perceptível no texto do autor: "Mesmo a chatice e a monotonia são para o leitor defeitos muito menores na composição do que uma tipografia excêntrica e jocosa". (MARTINS FILHO, 2008, p. 54)

\section{PERCEPÇÕES SOBRE LEITURAS}

$\mathrm{Na}$ tentativa de ultrapassar uma simples descrição do que se obteve como resultado da aplicação do questionário, procura-se aqui interpretar os resultados em suas relações com a literatura analisada e os que se extraiu das experiências editoriais. $\mathrm{O}$ questionário foi aplicado a 22 alunos de mestrado, sessenta de graduação e 31 de ensino médio.

Observa-se inicialmente que somente 3,7\% dos alunos de mestrado e 1,5\% dos alunos de graduação lêem livros em dispositivos eletrônicos $e$-book. A maioria deles faz a leitura do suporte eletrônico na própria tela do computador, enquanto $30 \%$ desses imprimem o conteúdo em papel para facilitar a leitura, o que corrobora afirmações obtidas na literatura. Esse comportamento, comum aos três níveis de ensino, é justificado pela afirmação de que o fazem por não ter tempo suficiente para a leitura completa, razão pela qual deixam para ler à noite ou nos finais de semana. Há também quem afirme não estar acostumado com a leitura na tela. Quanto aos aparelhos de leitura, a maioria não os conhece e os poucos que conhecem não os adquiriram. 


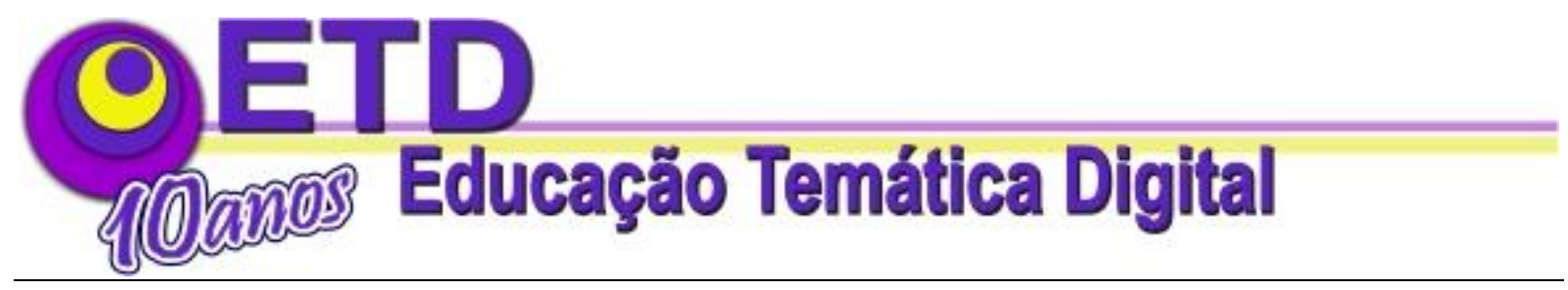

Sobre o tempo destinado à leitura, ratifica-se o que já se tem sido constatado em pesquisas sobre essa prática, ou seja, o estudante lê pouco, em média 6,5 horas por semana para o mestrando, 3,67 para os graduandos e menos de duas horas para o de ensino médio. Esse índice se relaciona a todos os tipos de leitura e suporte, em papel ou eletrônico.

O estudante não tem o costume de comprar de livros, com exceção dos mestrandos, dos quais $59,1 \%$ costumam comprar entre um e cinco livros anuais. Os estudantes de graduação e de nível médio, em sua maioria, não adquirem livros.

Quanto à leitura de fontes no suporte papel a preferência é para a leitura de lazer, seguida dos livros técnicos e acadêmicos pelos mestrandos e graduandos. A preferência pode ser influenciada pela predominância de mulheres nas turmas para as quais foram aplicados os questionários.

No suporte eletrônico as fontes mais consultadas tanto pelos mestrandos quanto pelos estudantes de graduação são de conteúdo científico, principalmente os artigos que estão disponíveis online. Quanto à leitura de fruição percebe-se pouca procura e utilização, o que pode ser explicado pela disponibilidade maior dos textos de literatura impressos.

Pode-se afirmar que o futuro do livro eletrônico ainda não apresenta posição consolidada, pois embora 36,4\% dos mestrandos afirmem que comprariam o livro eletrônico, $37 \%$ dos estudantes de graduação não comprariam. O percentual daqueles que só utilizariam se estivesse disponível gratuitamente (31\% dos mestrandos, 44,5\% dos graduandos e 54,8\% dos estudantes de ensino médio) ajusta-se a um perfil pouco propenso a esse tipo de leitura, sinalizando para a ausência de uma cultura formada para o uso desses dispositivos.

A consideração de que as editoras universitárias devam assumir posições de vanguarda diante de novas tecnologias e modos de produção reforça a premência do acompanhamento das tendências de uso dos instrumentos e materiais disponíveis ao leitor, para que sejam mobilizados comportamentos de leitura pertinentes aos interesses dos estudantes e à cultura da universidade. Se a cultura do livro eletrônico ainda não faz parte 


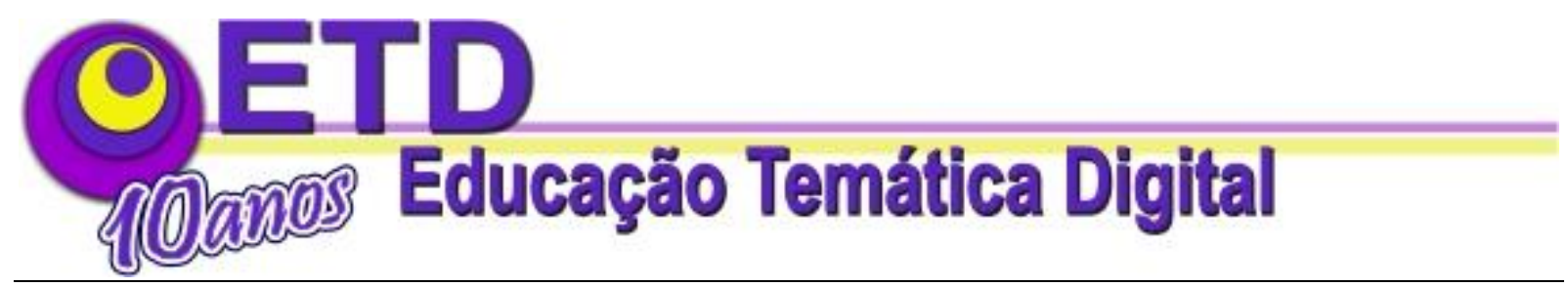

desse mundo ou não está consolidada como prática dos estudantes, tendo seu uso restrito principalmente a artigos científicos e leitura de jornais eletrônicos on-line, vale considerar a avisada sugestão dos bibliotecários consultados na pesquisa da Ithaka, iniciando-se por projetos mais restritos às necessidades de conteúdos específicos, em textos universitários dirigidos a públicos específicos, ou obras de referência, bases de dados ou fontes secundárias de informação.

Embora a pesquisa não tenha se dirigido aos motivos da pouca utilização dos $e$ books, a literatura analisa extensamente esse tema atribuindo essa rejeição em parte ao brilho da tela que cansa a leitura, ou ao inconveniente de sempre precisar de uma tomada para alimentar o equipamento eletrônico para sua leitura, embora já existam aparelhos com maior autonomia. Impõe-se a continuidade dos estudos para aprofundamento do tema e ampliação de possibilidades de conhecimento de outras variáveis que um estudo mais específico poderia oferecer.

\section{CONSIDERAÇÕES FINAIS}

Retomando a idéia de um outro olhar sobre o livro universitário e o leitor diante das novas tecnologias, pode-se concluir que o livro impresso, herdeiro das primeiras formas de registro em argila, das técnicas aperfeiçoadas do manuscrito, incorporando a organização e os subsídios de leitura, como índices, sumários e formato linear do texto, vem sofrendo efetivamente uma revolução com o advento dos meios eletrônicos. Essa transformação histórica fundamenta-se na minimização dos espaços de texto e de armazenagem, diante da explosão dos registros do conhecimento.

Análogo ao livro impresso, desde a capa até o índice, o e-book desenvolveu-se graças ao aperfeiçoamento de programas que imitam a diagramação de um impresso. Como hardware, oferece a qualidade da portabilidade, armazenagem de vários textos ou livros em um único exemplar, facilitando o transporte de muitos títulos num só suporte e permitindo a leitura em qualquer espaço, com pouca ou nenhuma iluminação. 


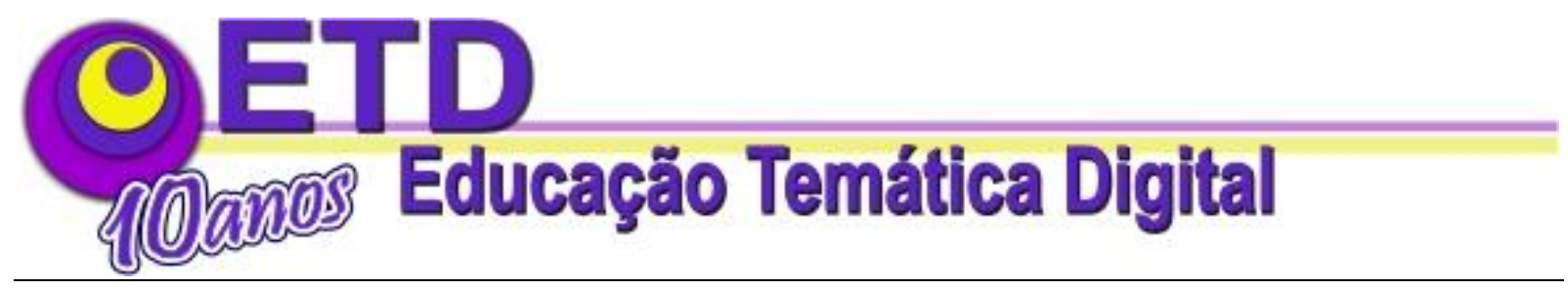

Embora ainda não utilizado com freqüência e até pouco apreciado, conforme os resultados da pesquisa, as expectativas de aperfeiçoamento são evidentes, tanto na literatura, quanto na experiência concreta de alguns editores.

As editoras, acompanhando o ritmo de transformações tecnológicas, inovam e criam serviços e produtos compatíveis à evolução desse campo, procurando atender a demanda pelo livro eletrônico, disponibilizando textos compatíveis com hardware e software, na tentativa de preservar os elementos de uma cultura editorial milenar. Textos podem ser transferidos instantaneamente de uma livraria na Web para uma leitora portátil e as edições não se esgotarão. Enquanto os livros de papel são objetos exemplares isolados, os eletrônicos podem incluir links em hipertexto para outros conteúdos, dispostos em outros textos, estimulando o leitor a uma leitura não-linear, dando-lhe liberdade de usar os links e as imagens conforme sua vontade, seu gosto e sua capacidade.

Mas se o livro eletrônico apresenta relativas vantagens sobre o impresso, no contexto brasileiro, como no de outros países periféricos, seu uso atinge uma camada restrita da sociedade, como se pode observar pelos resultados da pesquisa. Além do preço, existe outro fator restritivo ao acesso representado pela necessidade de importação do hardware.

Consideradas outras questões relativas à comodidade e aos estilos pessoais de leitura, pode-se afirmar que o livro impresso permanecerá por muito tempo incorporado ao acervo de bibliotecas e centros de documentação, convivendo com os novos formatos. Deverá continuar, portanto, fazendo parte do nosso cotidiano como o fazem os instrumentos musicais e tantos outros aparatos que o homem criou para registrar e transmitir seu conhecimento e expressar sua sensibilidade. 


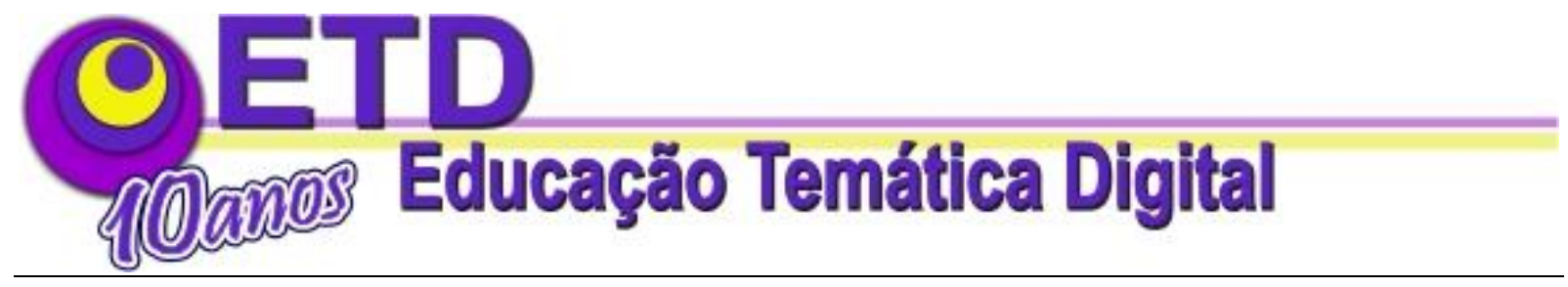

Se o livro, enquanto objeto de leitura, vive uma pluralidade de existências, sendo a eletrônica, segundo Chartier (1998a), apenas uma delas, prevalece a convivência entre o tradicional e o revolucionário, perceptível neste cenário de profundas mudanças pelas quais têm passado nossos objetos de leitura. As virtudes do livro eletrônico são descritas por escritores, editores e leitores, mas os chamados perigos que ele apresenta têm sido objeto de estudos e eventos, nos quais as contradições evidenciam sua pertinência.

A leitura alimenta-se, entretanto, de possibilidades inusitadas e caudatárias de tecnologias que se sucedem. Estas ameaçam um formato de livro chamado tradicional, como os demais formatos, alguns superados, como os tabletes de argila, outros sobreviventes como o códice, sem que se tenha perdido a percepção dos elementos culturais que os definiram. As tentativas de preservação dos elementos culturais vigentes, como ocorreu quando do aproveitamento dos valores estéticos do manuscrito nos incunábulos, assim como a coexistência dos formatos e dos acessórios a serviço do ato de ler demonstram que a diversificação de alternativas, a partir de princípios, critérios e desdobramentos formais específicos, é subsidiária de uma concepção mais ampla de leitura. Impossível definir os amantes do livro como "sobreviventes" da cultura do impresso, reivindicantes de uma forma tradicional do livro. Como intelectuais atuantes, eles revivem diante das diferenciações que o livro, objeto portador de textos, mais ou menos virtual, mas sempre concreto, apresenta. 


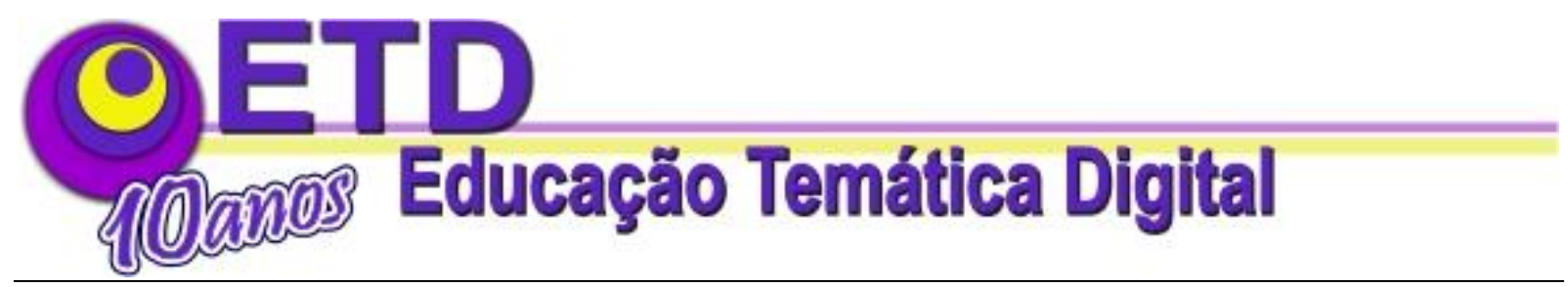

\section{REFERÊNCIAS}

BELLEI, S. L. P. O livro, a literatura e o computador. São Paulo, SP: EDUC; Florianópolis: UFSC, 2002.

BILAC, O. Ironia e pidedade. Rio de Janeiro, RJ: Francisco Alves, 1923.

BOLTER, J. D. Writing space: the computer, hypertext, and the history of writing. New Jersey: Lawrence Erlbaum Associates Publishers, 1991.

BORGES, J. L. O livro. São Paulo, SP: Edusp, 2008.

BRASIL. Portal Domínio Público. Brasília: MEC, 2009. Disponível em: <http://www.dominiopublico.gov.br $>$. Acesso em: 15 maio 2009.

BROWN, L.; GRIFFITHS, R.; RASCOFF, M. University publishing in a digital age. Ithaka Report, July 26, 2007. Disponível em: <http://www.ithaka.org/strategicservices/Ithaka\%20University\%20Publishing\%20Report.pdf>. Acesso em: 15 maio 2009.

CHARTIER, R. A aventura do livro: do leitor ao navegador. São Paulo, SP: Fundação Editora da UNESP, 1998. 159 p.

. A ordem dos livros: leitores, autores e bibliotecas na Europa entre os séculos XIV e XVIII. Brasília: Editora da Universidade de Brasília, 1994b.

Do códice ao monitor: a trajetória do livro. Estudos Avançados, IEA/USP, v. 8, n. 21, p. 185-199, 1994a.

COSCARELLI, C. V. Leitura em ambiente multimídia e a produção de inferências. In:

SIMPÓSIO BRASILEIRO DE INFORMÁTICA NA EDUCAÇÃ̃O, 7., 1996, Belo Horizonte. GUIMARÃES, A. M. (Ed.) Anais... Belo Horizonte: DCC/UFMG, 1996. p. 449-456.

EBOOKZINE. O eBook em 3 partes... 2004. Disponível em:

<http://www.ebookcult.com.br/ebookzine/oebookem3partes.htm>. Acesso em: 20 maio 2009.

EDITORA DA UNIVERSIDADE DO SAGRADO CORAÇÃO. Bauru, 2008. Disponível em: <http://www.edusc.com.br>. Acesso em: 15 maio 2009.

FUNDAÇÃO EDITORA DA UNIVERSIDADE ESTADUAL PAULISTA. São Paulo, 2009. Disponível em: <http://www.editoraunesp.com.br >. Acesso em: 15 maio 2009. 


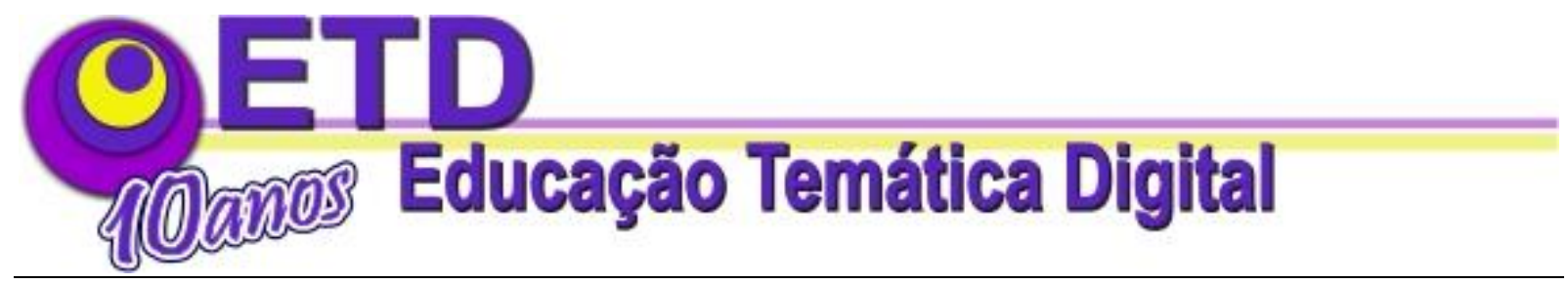

GONÇALVES-CHAVES, G. R. Leitura, aprendizagem e novas tecnologias: alguns desafios. Revista txt: leituras transdisciplinares de telas e textos, Belo Horizonte, n. 2, 2005.

JOHNSON, S. Cultura da interface: como o computador transforma nossa maneira de criar e comunicar. Rio de Janeiro, RJ: Jorge Zahar Ed., 2001.

KUCHENBECKER, V. ABEU em rede. [Portal da ABEU], São Paulo, 05 abr. 2009. Entrevista. Disponível em: 〈http://www.abeu.org.br/noticias.php?id_noticia=173 > . Acesso em: 29 maio 2009.

LOTH, R. W. Leituras do hipertexto: viagem ao Dicionário Kazar. Florianópolis: Ed. UFSC, 2003.

MARQUEZI, D. A revoluçaõ dos livros virtuais. Super Interessante, São Paulo, v. 14, n. 10, p. $78-79$, out. 2000.

MARTINS FILHO, P. A arte invisível. 2. ed. São Paulo, SP: Ateliê Editorial, 2008.

Como os livros são financiados. ComCiência: Revista Eletrônica de Jornalismo

Científico, n. 103, nov. 2008. Disponível em:

<http://www.comciencia.br/comciencia/handler.php? section=8\&edicao $=40 \& i d=483>$. Acesso em: 20 maio 2009.

PERSONA, M. O fim do livro. O Estado do Paraná, Curitiba, 15 out. 2000. Informática, p. 2.

RODRIGO, E. O futuro das editoras universitárias e as mídias eletrônicas. ComCiência:

Revista Eletrônica de Jornalismo Científico, n. 103, nov. 2008. Disponível em:

$<$ http://www.comciencia.br/comciencia/handler.php?section=8\&edicao=40\&id=483 > . Acesso em: 20 maio 2009.

SILVA, G. M. S.; BUFREM, L. S. Livro eletrônico: a evolução de uma idéia. In: CONGRESSO BRASILEIRO DE COMUNICAÇÃO-INTERCOM, 24., Campo Grande, 2001. Anais... Campo Grande: UNIDERP, 2001.

SILVA, G. B. S. A utilização de mapas de tópicos na integração de conteúdos hipertextuais semanticamente estruturados. 2008. Dissertação (Mestrado em Ciência da Informação) - Escola de Ciência da Informação, Universidade Federal de Minas Gerais, Belo Horizonte, 2008.

SORRIBAS, T. V. Informação e artefatos culturais de leitura. Projeto de pesquisa (Curso de Gestão da Informação) - Setor de Ciências Sociais Aplicadas, Universidade Federal do Paraná, 2009. 


\section{PESQUISA}

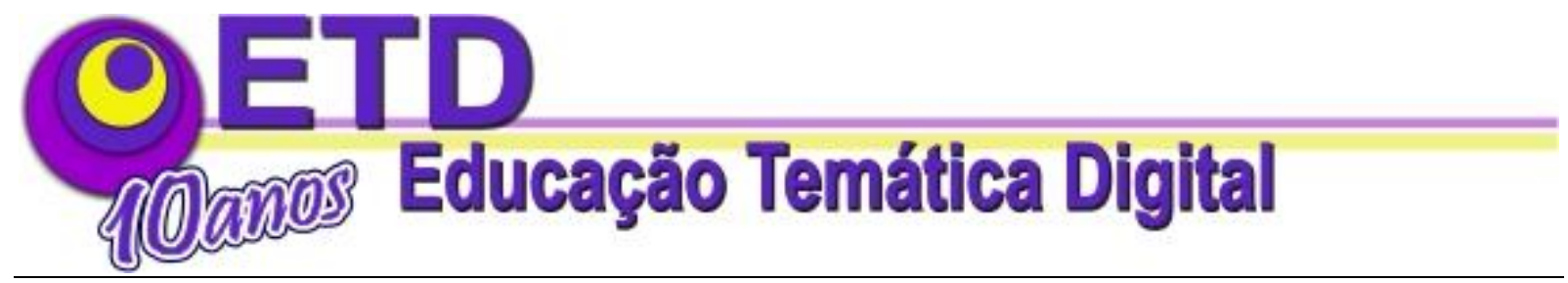

UNIVERSIDADE DE SÃO PAULO. BibVirt: Biblioteca Virtual do Estudante de Língua Portuguesa. São Paulo, [2009?]. Disponível em: <http://www.bibvirt.futuro.usp.br>. Acesso em: 15 maio 2009.

VOGT, C. O livro e as editoras universitárias. ComCiência: Revista Eletrônica de Jornalismo Científico, n. 103, nov. 2008. Disponível em:

$\langle$ http://www.comciencia.br/comciencia/handler.php?section $=8 \&$ edicao $=40>$. Acesso em: 20 maio 2009.

ZILBERMAN, R. Fim do livro, fim dos leitores? São Paulo, SP: Senac, 2001. 


\section{Leilah Santiago Bufrem}

Doutora em Ciências da Comunicação pela Universidade de São Paulo;

Pós-Doutora pela Universidad Autónoma de Madrid;

Professora Titular da Universidade Federal do Paraná, Curitiba, Brasil E-mail: leilah@ufpr.br

Tidra Viana Sorribas Aluna do curso de Gestão da Informação da Universidade Federal do Paraná;

Voluntária de Iniciação Científica

E-mail: tidra vs@yahoo.com

Recebido em: 02/08/2009 Publicado em: $23 / 12 / 2009$ 